\title{
ANALISIS PEER TO PEER LENDING DI INDONESIA
}

\author{
Risna Kartika1 , Nana Darna², Iwan Setiawan ${ }^{3}$ \\ 1,2,3Fakultas Ekonomi Unicersitas Galuh \\ email: 1risnakartika@gmail.com,2nanadarna@yahoo.co.id,3iwan.feunigal@gmail.com
}

\section{Kata kunci: peer to peer lending, financial technology, pembiayaan, SMEs}

Keywords: peer to peer lending, financia technology, financing, UMKM

Kartika, R. Darna, Nana dan Setiawan. I. (2019). Analisis Peer To Peer Lending di Indonesia. Akuntabilitas: Jurnal Ilmiah IlmuIlmu Ekonomi, 12(2), 75-86

\begin{abstract}
ABSTRAK
Permasalahan dalam penelitian yang timbul dari perkembangan fintech diantaranya ialah mengenai keamanan data dan kepastian hukum pinjaman berbasis online sehingga berdampak pada risiko potensial bagi konsumen dan stabilitas serta integritas keuangan. Tujuan dari penelitian ini ialah menganalisis perkembangan peer to peer lending di Indonesia, yang ditinjau berdasarkan peraturan- peraturan lembaga terkait dan studi literatur. Penelitian ini menggunakan metode deskriptif dengan pendekatan literature review. Hasil dari penelitian ini mendeskripsikan jenis fintech yang masuk dalam kategori dominan di Indonesia adalah peer to peer lending, pengguna peer to peer lending oleh usia produktif dengan presentase 70\%. Pada Oktober 2019 jumlah pinjaman tersebut meningkat sebesar $200,01 \%$. Pemerintah melakukan pengawasan mengenai peer to peer lending melalui tiga lembaga yaitu Bank Indonesia, Kominfo dan OJK. Ketiga lembaga tersebut mengawasi kegiatan operasi dari mulai penyelenggaraan hingga perlindungan konsumen. Peer to peer lending menyasar UMKM yang layak namun belum bisa mendapatkan fasilitas kredit perbankan. Peer to peer lending dapat membantu mengembangkan UMKM dari segi keuangan, khususnya bidang pembiayaan.
\end{abstract}

\section{ABSTRACT}

Problems arising from the development of fintech include data security and legal certainty of online-based loans so that it impacts on potential risks to consumers and financial stability and integrity. The purpose of this study is to analyze the development of peer to peer lending in Indonesia, which is reviewed based on relevant institutional regulations and literature studies. This research uses a descriptive method with literature review. The results of this study describe the types of fintech that fall into the dominant category in Indonesia are peer to peer lending, peer to peer lending users by productive age with a percentage of $70 \%$. In October 2019 the number of loans increased 200.01\%. The government supervises peer to peer lending through three institutions there are Bank Indonesia, the Ministry of Communication and Information and OJK. The three institutions oversee operations from the start up to consumer protection. Peer to peer lending targets MSMEs that are feasible but cannot obtain bank credit facilities. Peer to peer lending can help develop MSMEs in financial terms, especially in the field of financing.

\section{PENDAHULUAN}

Revolusi Industri 4.0 telah memperkenalkan teknologi produksi masal yang fleksibel (Kagermann et al, 2013). Revolusi digital merupkan istilah lain dari industri 
4.0. Disebut revolusi digital karena terjadinya proliferasi komputer dan otomatisasi pencatatan di semua bidang. Industri 4.0 dikatakan era disrupsi teknologi karena otomatisasi dan konektivitas di sebuah bidang akan membuat pergerakan dunia industri dan persaingan kerja menjadi tidak linear (Tjandrawinata, 2016). Dengan adanya revolusi digital ini muncul berbagai inovasi disegala bidang, termasuk dalam bidang keuangan yang diakibatkan dari permintaan dan gaya hidup masyarakat. Kemajuan pesat dalam teknologi digital mengubah lanskap ekonomi dan keuangan (World Bank, 2019). Financial Tecnology atau lebih popular disebut dengan Fintech merupakan inovasi yang menggabungkan antara financial service dan teknologi sebagai alternatif pilihan pada masyarakat selain lembaga keuangan konvensional (Haryono, 2019).

Perkembangan teknologi yang terjadi saat ini membuat developer aplikasi mobile berinovasi dengan menciptakan banyak jenis fintech. Salah satunya yaitu jenis fintech di bidang pembiayaan, seperti supply chain finance, crowdfunding, peer to peer lending. Fintech tersebut menawarkan layanan yang memudahkan konsumen dalam penggunaan jasa keuangan (OJK, 2019). Fintech sudah dikenal oleh masyarakat luas, tidak hanya dikalangan wirausaha terlebih kalangan anak muda pengguna aktif internet. Pemanfaatan Fintech ini perlu dibarengi dengan regulasi yang baik dan tepat. Fenomena tersebut menunjukkan keberadaan fintech mengancam produk perbankan atau lembaga keuangan lain. Permasalahannya, teradapat beberapa regulasi yang masih perlu diperhatikan diantaranya mengenai tanda tangan elektronik, penyelenggaraan know your customer digital, keamanana data, kepastian hukum pinjaman berbasis online dan elektronifikasi pembayaran (Rizal, Maulina, \& Kostini, 2018).

Di Indonesia sendiri Peer to Peer Landing banyak diminati masyarakat dengan berbagai alasan salah satunya ialah karena kemudahan dan singkatnya waktu pencairan dana, hal ini terbukti dari kenaikan jumlah pinjaman yang disalurkan dari Desember 2018 sampai dengan Oktober 2019 sebesar 200,01\% (OJK, 2019), data rekening peer to peer lending baik dari lender di area Jawa, Luar Jawa dan Luar Negeri yang cenderung naik dari bulan Januari sampai dengan Desember tahun 2018 yang tersaji dalam Gambar 1. 


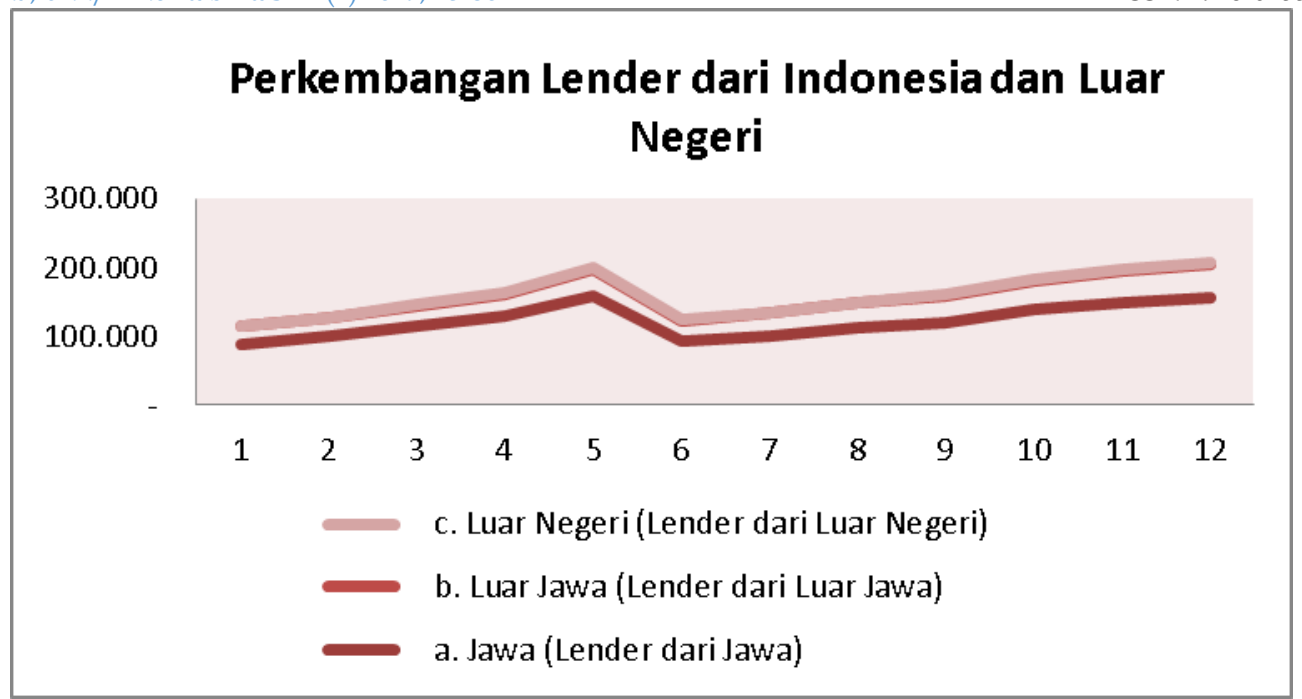

Gambar 1. Perkembangan Rekening Lender tahun 2018

Sumber: Statistik Fintech OJK (2018)

Begitupula pada signifikannya peningkatan jumlah rekening Borrower di Indonesia dari Januari 2018 sampai dengan Desember 2018, ini menggambarkan bahwa Fintech semakin diminati terutama jenis peer to peer lending.

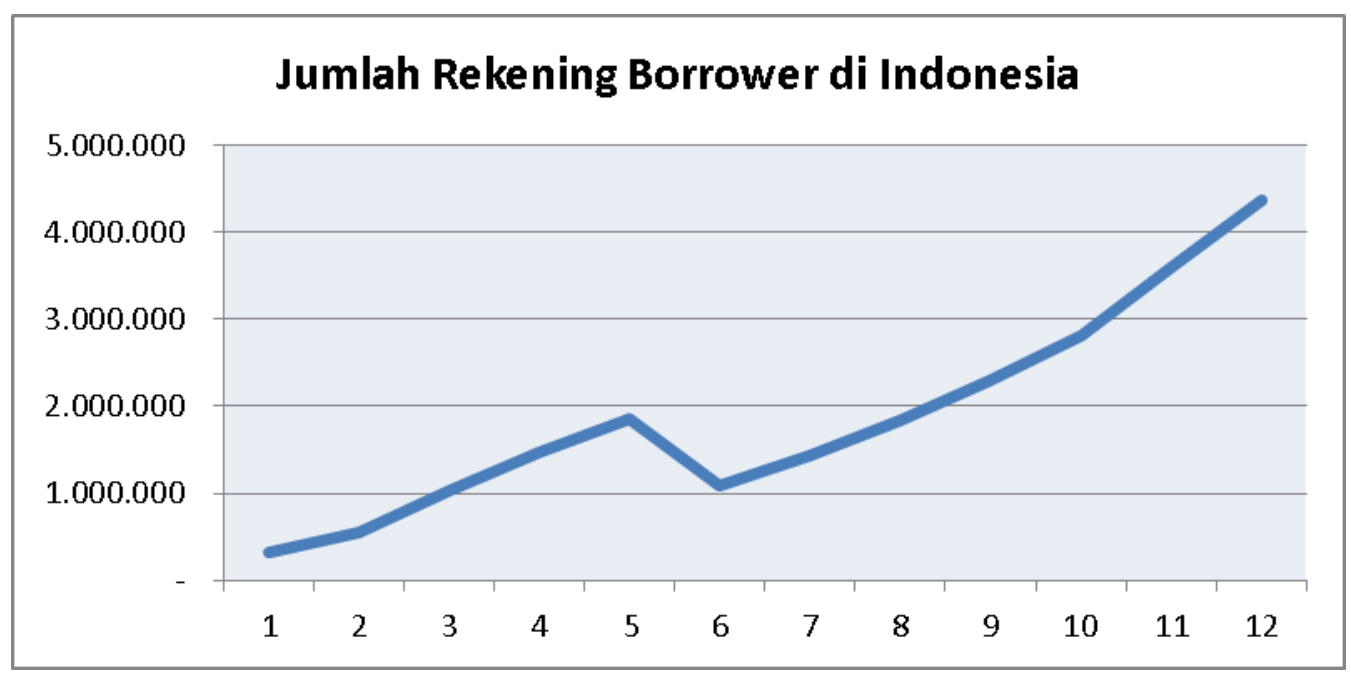

Gambar 2. Perkembangan Jumlah Rekening Borrower tahun 2018 Sumber: Statistik Fintech OJK (2018)

Penelitian terdahulu mengenai Fintech di Indonesia berkembang cukup pesat. Peer to peer lending merupakan jenis fintech yang paling banyak diminati. Tercatat tiga tiga perusahaan startup yang memiliki pangsa pasar cukup tinggi yaitu Amartha, Modalku dan Investree, hal ini dikarenakan besarnya permintaan pembiayaan usaha bagi masyarakat yang belum layak didanai oleh perbankan (Rizal et al., 2018). 
Dampak dari perkembangan Fintech pada layanan keuangan professional di Nigeria (Mlanga, 2019). Penelitian peran Fintech dikaitkan dengan UMKM yang tidak memperoleh fasilitas pinjaman dari perbankan (Ahmad, 2019; Rizal et al., 2018). Dalam penelitian lain mengkaji mengenai penerapan prinsip kehati-hatian dalam pinjaman berbasis fintech (Dwinanda, 2019). Selain itu, fintech memberikan ancaman serta peluang pada industri perbankan, yang kemudian membuat layanan perbankan menjadi lebih baik (Basuki \& Husein, 2018). Fintech mampu meningkatkan kualitas layanan pada industri perbankan karena fintech dapat menjangkau seluruh pasar secara geografis (Chrismastianto, 2017).

Penelitian analisis SWOT mengenai Fintech pada dunia perbankan di Indonesia (Basuki \& Husein, 2018; Chrismastianto, 2017; Marginingsih, 2019; Muchlis, 2018). Penelitian Fintech dikaitkan dengan perbankan islam atau syariah (Darussalam, Tutuko, Dahlan, Hudaifah, \& Tajang, 2018; Nurul \& Ningrat, 2018). Berkaitan dengan dokumen elektronik pada Fintech selayaknya dikelola dengan berlandas pada prinsip dasar yang melandasi dalam perancangan formulir/dokumen, memenuhi keabsahan formal maupun materil serta mempertimbangkan kelemahan-kelemahan yang ada. Dengan demikian dokumen tersebut akurat, jujur, jelas, tidak menyesatkan; menjadi dokumen yang bernilai sebagai alat bukti sesuai dengan yang tercantum dalam Peraturan Otoritas Jasa Keuangan RI Nomor 77/Pojk.01/2016 mengenai Layanan Pinjam Meminjam Uang Berbasis Teknologi Informasi pasal 30 (Tripalupi, 2019). Berdasarkan analisis SWOT pada Fintech pembiayaan pada perbankan syariah diketahui bahwa perkembangan product development akan semakin baik, dimana Fintech akan selalu dapat mengikuti perkembangan yang ada dan mudah untuk disesuaikan, sesuai dengan perkembangan kebutuhan nasabah (Muchlis, 2018). Penelitian selanjutnya mengenai perkembangan dan dampak Fintech terhadap industri keuangan syariah di Jawa Tengah (Ansori, 2019). Selanjutnya penelitian mengenai Fintech yang dikaitkan dengan performa perbankan konvensional di beberapa Negara (Anagnostopoulos, 2018; Jagtiani \& Lemieux, 2018; Phan, Narayan, Rahman, \& Hutabarat, 2019; Thakor, 2019). Perbedaanya, penelitian ini menganalisis Peer to Peer Lending di Indonesia. 
Beberapa jenis fintech dibidang pembiayaan yang diantaranya peer to peer lending, sektor Crowdfunding, Supply Chain Finance, dan lain-lain juga sedang diminati masyakarat Indonesia karena Fintech dengan mudah memasuki masyarakat yang belum mengenal fasilitas perbankan yang tersedia. Fintech menciptakan peluang dan tantangan baru untuk sektor keuangan, mulai dari konsumen, lembaga keuangan, hingga regulator. Fintech menawarkan banyak peluang bagi pemerintah, mulai dari membuat sistem keuangan mereka lebih efisien dan kompetitif hingga memperluas akses ke layanan keuangan bagi masyarakat yang kurang terlayani. Namun, hal itu juga dapat menimbulkan risiko potensial bagi konsumen, investor dan yang lainnya terhadap stabilitas dan integritas keuangan (World Bank, 2019). Tujuan dari penelitian ini ialah menganalisis perkembangan peer to peer lending di Indonesia, yang ditinjau berdasarkan peraturan- peraturan lembaga terkait dan studi literatur. Maka dari itu penelitian ini mengambil judul "Bagaiman aktivitas Peer to Peer Lending di Indonesia?".

\section{METODE PENELITIAN}

Penelitian ini menggunakan metode deskriptif serta pendekatannya menggunakan literature review. Literature review adalah mendeskripsikan suatu teori atau temuan yang diperoleh dari berbagai sumber yang dijadikan atau digunakan sebagai dasar / referensi dalam menyelesaikan suatu masalah (Prawirasasra, 2018). Pengambilan data dilakukan dengan cara. Penelitian ini menggunakan 3 tahao teknik analisis data, yang terdiri dari reduksi data, penyajian data dan penarikan kesimpulan (Hedynata \& Radianto, 2016). Reduksi data dilakukan dengan dokumentasi, selanjutnya penyajian data dilakukan dengan mengkategorikan dan menyusun kumpulan data informasi agar memudahkan penarikan kesimpulan dan pengambilan tindakan, dan yang terakhir ialah penarikan kesimpulan.

\section{PEMBAHASAN}

Pada beberapa tahun belakangan ini terdapat sumber permodalan alternatif berbasis teknologi yang disebut Fintech (Rizal et al., 2018). Fintech telah merambah beberapa sektor, seperi jasa pembayaran, pinjaman, perencanaan keuangan, pendanaan, riset keuangan dan remitansi (Ahmad, 2019). Salah satu financial 
technology yang cukup popular di Indonesia yaitu peer to peer lending atau biasa disebut P2P, platform tersebut memberikan layanan yang mempertemukan antara kreditur dengan debitur melalui media digital (Phan et al., 2019). Hingga tahun 2019 bulan Oktober terdapat 127 fintech P2P yang terdaftar atau memiliki ijin dari OJK, dari keseluruhan fintech yang terdaftar 93\% kegiatan usahanya berbentuk konvensional dan 7\% sisanya berbentuk syariah. Perkembangan P2P di Indonesia disajikan dalam infografis pada gambar 3.

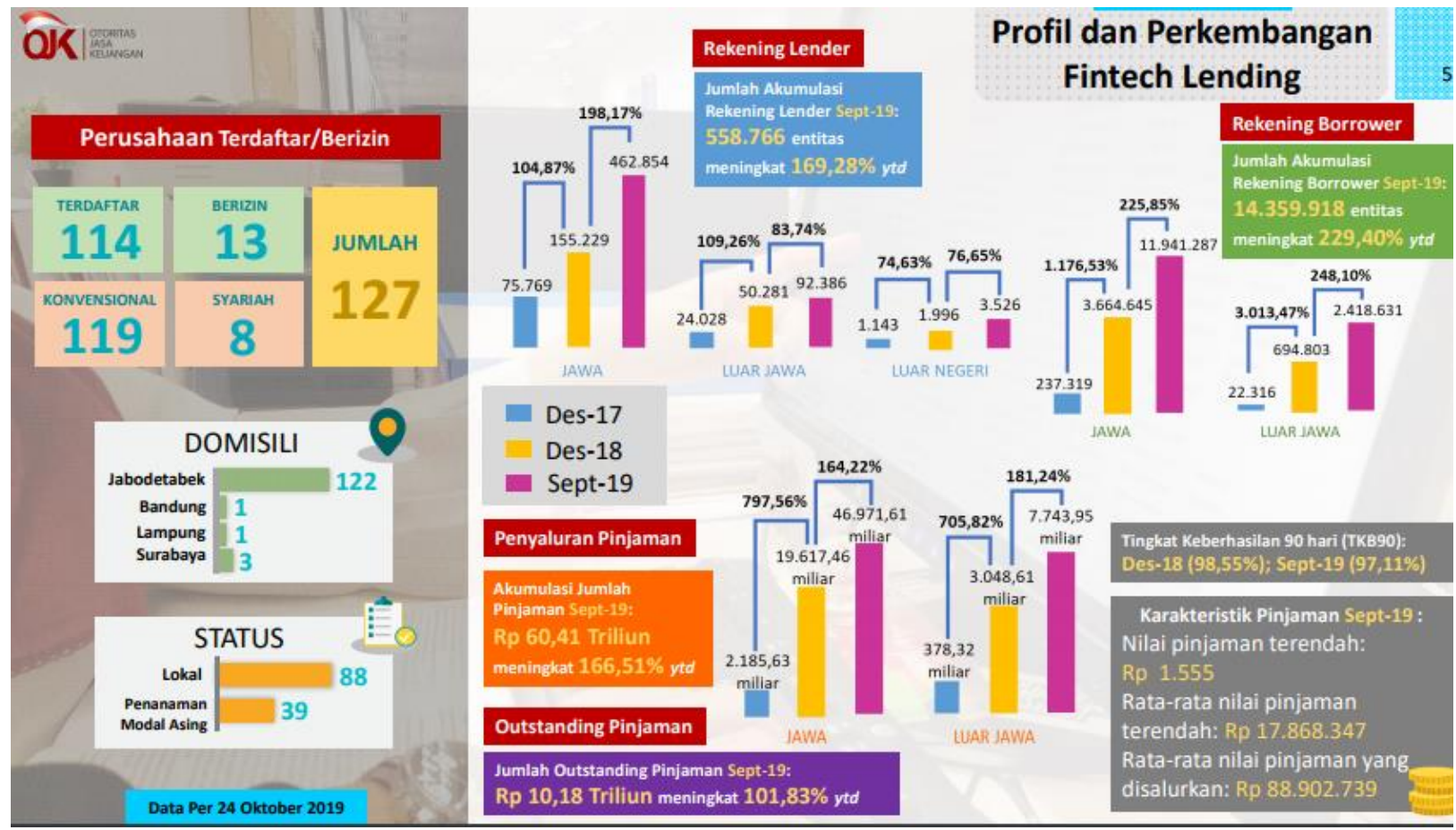

Gambar 3. Infografis P2P di Indonesia

Sumber: OJK (2019)

Usia produktif antara 19 sampai dengan 34 tahun mendominasi pengguna Fintech Peer to Peer Lending yaitu sebesar 70,56\% diikuti oleh usia produktif antara 35 sampai dengan 54 tahun sebesar 27,47\% sisanya diikuti oleh usia lebih dari 54 tahun dan kurang dari 19 tahun. Hal ini juga menunjukkan bahwa pengguna P2P masih di dominasi oleh penduduk usia produktif dan pengguna internet aktif, hal ini dapat tercermin dalam infografis pada Gambar 4. 

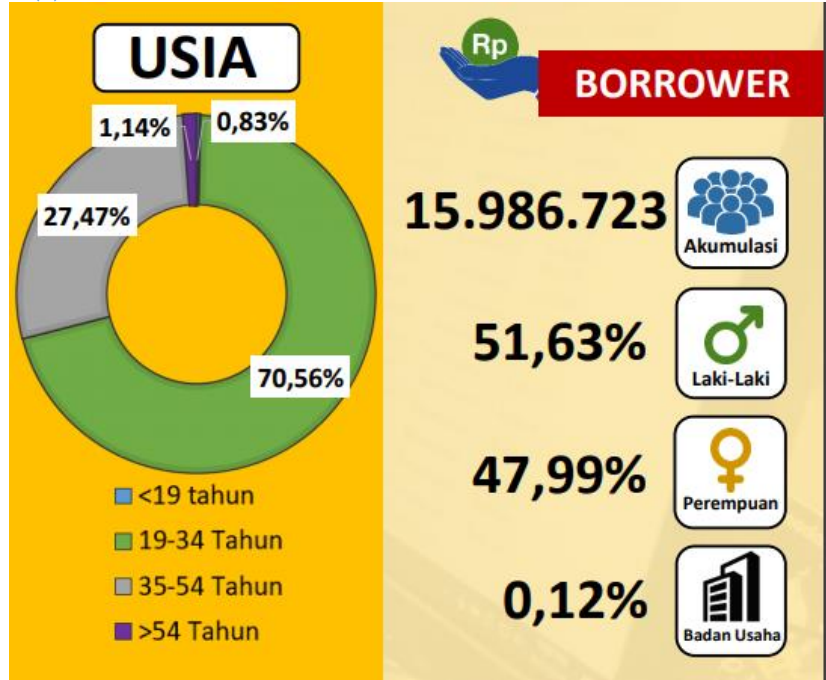

Gambar 4. User P2P

Sumber: OJK (2019)

Akumulasi jumlah pinjaman sampai dengan Oktober 2019 ialah Rp. 67.999,88 miliar meningkat 200,01\% year to date. Rata-rata pinjamaan yang disalurkan sebesar Rp. 88.902.739, jumlah akumulasi penyaluran pinjaman berdasarkan provinsi tersaji dalam infografis pada Gambar 5.

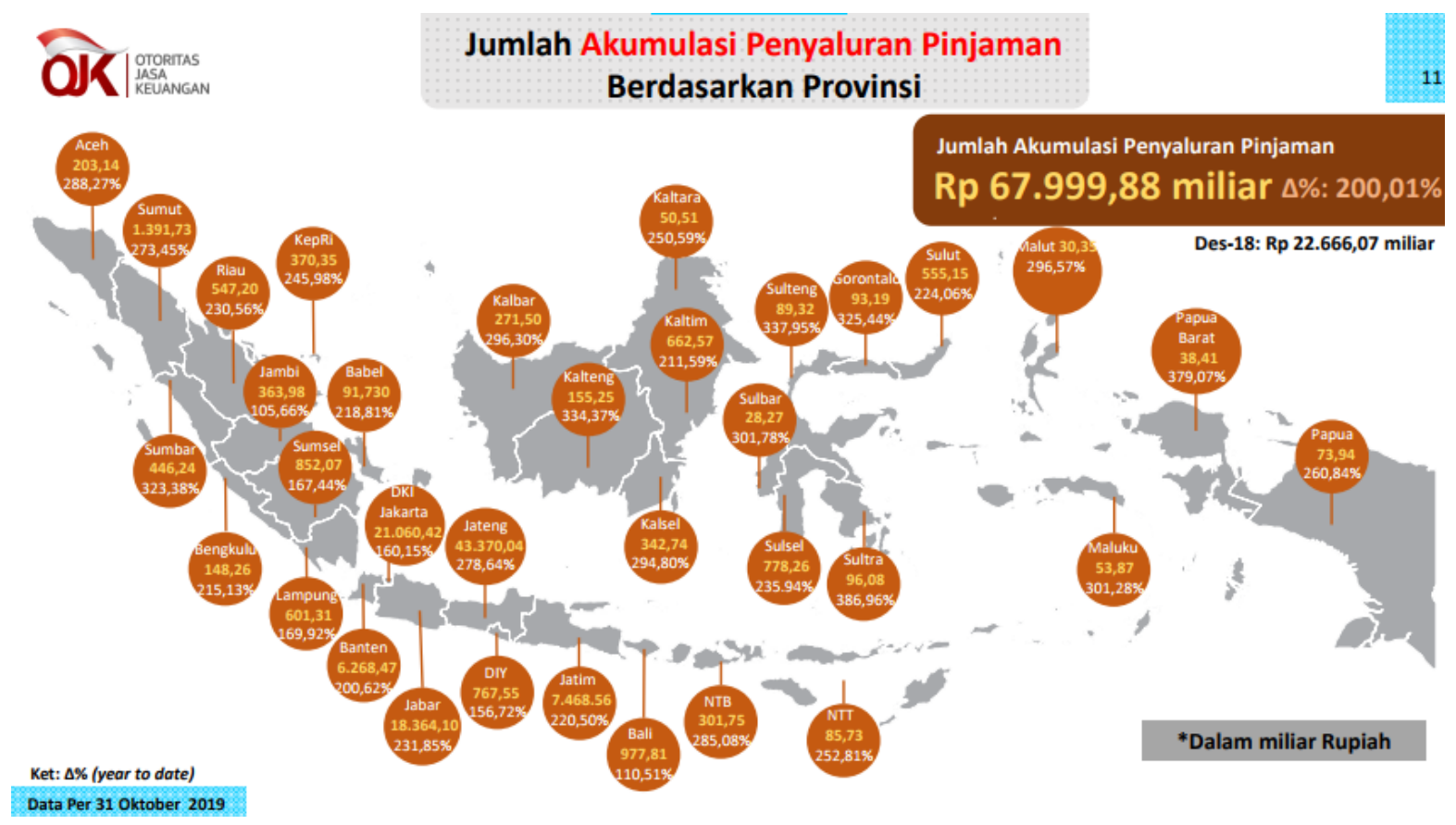

Gambar 5. Akumulasi Penyaluran Pinjaman Berdasarkan Provinsi per

Oktober 2019

Sumber: OJK (2019) 
Pengaturan Fintech saat ini merupakan tuntutan global bagi industri keuangan. Saat ini masalah yang dihadapi oleh negara maju dan negara berkembang seperti Indonesia adalah sama yaitu bagaimana mengembangkan Fintech. Harapannya di kemudian hari pertumbuhan Fintech di Indonesia dapat berkembang dengan baik dan aman (Rizal et al., 2018). Untuk meminimalisir risiko dan mengendalikan perkembangan Fintech, pemerintah membuat berbagai peraturan. Peraturan Fintech di Indonesia dibuat oleh tiga institusi pemerintahan seperti Kominfo, OJK dan Bank Indonesia. Sebagai langkah dasar, OJK menerbitkan POJK No. 77/ POJK.01/2016 mengena layanan peminjaman uang berbasis fintech. Pertauran selanjutnya yang masih berkaitan yaitu Surat Edaran OJK (SEOJK) nomor 18/SEOJK.02/2017, POJK tersebut mengatur kegiatan usaha P2P mulai dari penyediaan, pengelolaan hingga pengoperasian layanan pinjaman uang berbasis teknologi informasi, maksimum pinjaman yang diatur oleh OJK ialah sebesar dua Miliar Rupiah.Aspek perlindungan konsumen yang diatur pada POJK P2P Lending No. 1/POJK.07/ 2013 mengatur mengenai penyedia jasa wajid memberikan informasi actual yang bersifat akurat. Penyedia jasa juga memiliki kewajiban untuk menggunakan istilah sederhana pada berbagai aplikasi yang digunakan untuk kegiatan P2P agar mudah di pahami oleh pengguna. Selain itu penyedia jasa berkewajiban untuk memiliki SOP berkaitan dengan dokumen elektronik, sert apoin yang terpenting ialah penyedia jasa wajib merahasiakan data pengguna.

Peraturan selanjutnya yang dikeluarkan oleh Bank Indonesia terkait perlindungan konsumen diatur dalam PBI No. 18/40/PBI/ 2016 mengenai transaksi Salah satu perlindungan konsumen yang diatur dalam UU ITE adalah mengenai perlindungan data pribadi. UU ITE mewajibkan penggunaan setiap informasi melalui media elektronik yang menyangkut data pribadi seseorang, harus dilakukan atas persetujuan orang yang bersangkutan. UU ITE juga mewajibkan setiap pelaku usaha yang menyelenggarakan sistem elektronik harus menyelenggarakan sistem secara andal dan aman serta bertanggung jawab terhadap beroperasinya sistem elektronik sebagaimana mestinya. Beberapa pertauran Peraturan menteri atau Permen Kominfo guna memberikan rasa aman kepada konsumen, diatur dalam Permen Kominfo RI Nomor 20 Tahun 2016 , Permen Kominfo Nomor 5 Tahun 2016 
dan Permen Kominfo RI Nomor 4 Tahun 2016 tentang Sistem Manajemen Pengamanan Informasi.

Tingginya permintaan pembiayan di Indonesia membuat P2P Lending berpeluang besar untuk berkembang dibandingkan platform fintech lainnya. Pembiayaan UMKM merupakan pangsa pasar terbesar (Rizal et al., 2018). Dalam aktivitas P2P lending terdapat dua kategori debitur, yaitu Creditworthy dan Bankworhty. Creditworthy adalah debitur yang memiliki kemampuan bayar yang baik, tetapi belum mampu memenuhi kualifikasi pinjaman perbankan. Sedangkan Bankworthy merupakan debitur yang sudah lolos analisis kredit (5C). sehingga P2P lending dapat menjadi pilihan alternative bagi UMKM yang bekum mendapatkan fasilitas pembiayaan perbankan (Ahmad, 2019). Perbedaan lain antara pinjaman P2P lending dengan kredit perbankan ialah P2P lending lebih beresiko karena tanpa agunan dan nilai pinjaman maksimal ialah dua miliar (Ahmad, 2019).

Meningkatkatnya jumlah layanan P2P lending berdampak pada pertumbuhan UMKM sehingga mampu memperkuat ekonomi nasional. Di beberapa Negara, diantaranya Inggris yang menjadi salah satu negara yang memiliki julukan 'Fintech friendly'. Financial Conduct Authority (FCA) meluncurkan Innovation Hub dimana bisnis yang teregulasi maupun yang belum teregulasi dapat memperkenalkan produk dan layanan keuangan yang inovatif kepada pasar. Melalui Innovation Hub, FCA juga membuka kerjasama dengan Australia Securities and Investments Commission (ASIC) dan Monetary Authority of Singapore. FCA memfasilitasi masuknya perusahaan dari luar negeri yang inovatif ke Inggris dan kemudian memfasilitasi upaya pengembangan perusahaan tersebut. Dengan strategi seperti ini, FCA dapat meningkatkan kompetisi inovasi dan persaingan di pasar jasa keuangan di Inggris (OJK, 2019). Layanan P2P diharapkan dapat diatur dan diawasi lebih optimal oleh pemerintah guna mendorong peningkatan kesejahteraan masyarakat.

\section{KESIMPULAN}

Peer to Peer Lending (P2P) merupakan salah stau platform fintech yang paling banyak diminati oleh masyarakat. Presentase pengguna P2P di Indonesia sebanyak 70,56\% merupakan usia produktif dengan akumulasi pinjaman yang meningkat $200,01 \%$ year to date. Bentuk pengawasan dari pemerintah berkaitan dengan P2P 
18/SEOJK.02/2017, POJK No. 1/POJK.07/2013, PBI No. 18/40/PBI/2016, Permen Kominfo RI Nomor 20 Tahun 2016 , Permen Kominfo Nomor 5 Tahun 2016 dan Permen Kominfo RI Nomor 4 Tahun 2016. Perbedaan P2P lending dengan perbankan salah satunya ialah dalam hal target pasar yang dituju, P2P lending lebih menyasar UMKM yang memiliki kemampuan usaha dan bayar yang baik namun belum memperoleh fasilitas pembiayaan dari perbankan. P2P lending dapat membantu mengembangkan UMKM dari segi keuangan, khususnya bidang pembiayaan. Perkembangan UMKM ini diharapkan dapat mendorong perekonomian nasional.

\section{DAFTAR PUSTAKA}

Ahmad, F. N. I. (2019). Peran Financial Technology dalam Meningkatkan Keuangan Inklusif pada UMKM Abstrak. Bjb University, 5, 1-14.

Anagnostopoulos, I. (2018). Fintech and Regtech: Impact on Regulators and Banks. Journal of Economics and Business. https:/ / doi.org/10.1016/j.jeconbus.2018.07.003

Ansori, M. (2019). Perkembangan dan Dampak Financial Technology (FINTECH) Terhadap Industri Keuangan Syariah di Jawa Tengah. Wahana Islamika: Jurnal Studi Keislaman, 5(1), 31-45.

Basuki, F. H., \& Husein, H. (2018). Analisis SWOT Financial Technology Pada dunia Perbankan di Kota Ambon. Manis, 2(1), 60-74.

Chrismastianto, I. A. W. (2017). Analisis SWOT Implementasi Teknologi Finansial Terhadap Kualitas Layanan Perbankan di Indonesia. Jurnal Ekonomi Dan Bisnis, 20(1), 133-144.

Darussalam, A. Z., Tutuko, B., Dahlan, A., Hudaifah, A., \& Tajang, A. D. (2018). Islamic Financial Technology Towards The Advancement of Islamic Banking In Indonesa. Nisbah, 4(2), 171-181.

Dwinanda, A. R. D. (2019). Penerapan Prinsip Kehati-Hatian Dalam Layanan Pinjam Meminjam Uang Berbasis Teknologi Informasi Pada Situs Uangteman.com. Jurist-Diction, 2(3), 819-834.

Hedynata, M. L., \& Radianto, W. E. D. (2016). STRATEGI PROMOSI DALAM MENINGKATKAN PENJUALAN LUSCIOUS CHOCOLATE POTATO SNACK. 
PERFORMA: Jurnal Manajemen Dan Start-Up Bisnis, 1(April).

Jagtiani, J., \& Lemieux, C. (2018). Do Fintech Lenders Penetrate Areas That Are Underserved by Traditional Banks? Journal of Economics and Business. https:// doi.org/10.1016/j.jeconbus.2018.03.001.

Kagermann, H., Wahlster, W., \& Helbig, J.(2013). Recommendations for Implementing the Strategic Initiative Industrie 4.0. Industrie 4.0 Working Group, Germany, diakses pada tanggal 15 Januari 2019.

Marginingsih, R. (2019). Analisis SWOT Technology Financial ( FinTech ) Terhadap Industri Perbankan. Cakrawala: Jurnal Humaniora Bina Sarana Informatika, 19(1), $55-60$.

Mlanga, S. (2019). Implications of Financial Technology for Professionals in Financial Services in Nigeria, (172).

Muchlis, R. (2018). Analisis SWOT Financial Technology (Fintech) Pembiayaan Perbankan Syariah di Indonesia (Studi Kasus 4 Bank Syariah di Kota Medan). At- Tawassuh, 3(2), 335-357.

Nurul, M., \& Ningrat, R. G. (2018). ADOPSI TEKNOLOGI MUSLIM , SIKAP , DAN INTENSI PEMBELIAN PRODUK INVESTASI ISLAM MENGGUNAKAN FINANCIAL TECHNOLOGY. Journal of Economics and Business Aseanomics (JEBA), 3(2), 155-175.

Phan, D., Narayan, P. K., Rahman, R. E., \& Hutabarat, A. R. (2019). Do Financial technology Firms Influence Bank Performance. Pacific-Basin Finance Journal, 101210. https://doi.org/10.1016/j.pacfin.2019.101210

Prawirasasra, K. P. (2018). Financial Technology in Indonesia: Disruptive or Collaborative? Reports on Economics and Finance, 4(2), 83-90.

Rizal, M., Maulina, E., \& Kostini, N. (2018). Fintech As One Of The Financing Solutions For SMEs. AdBispreneur: Jurnal Pemikiran Dan Penelitian Administrasi Bisnis Dan Kewirausahaan, 3(2), 89-100.

Thakor, A. V. (2019). Fintech and banking: What do we know? Journal of Financial Intermediation, (July). https://doi.org/10.1016/j.jfi.2019.100833

Tjandrawinata, R. R. (2016). Industri 4 . 0: Revolusi Industri Abad Ini dan Pengaruhnya pada Bidang Kesehatan dan Bioteknologi. Medicinus, Dexa 
Laboratories of Biomolecular Sciences (DLBS), 29(1), 31-39.

Tripalupi, R. I. (2019). Pengelolaan Dokumen Elektronik Layanan Jasa Keuanga

Berbasis Financial Technology (Fintech). Jurnal Ilmu Akuntansi Dan Bisnis SYariah, 1(1), 13-22.

Bank Indonesia, 2019.

https://www.bi.go.id/id/sistem-pembayaran/Fintech/Contents/default.aspx, diakses pada tanggal 13 Janurai 2020.

Haryono, 2019.

https:/ / finance.detik.com/Fintech/d-4674364/Fintech-disebut-jadi-saingan-

bank-konvensional-benarkah , diakses pada tanggal 10 Januari 2020.

OJK, 2019.

https:// www.ojk.go.id/id/kanal/iknb/data-dan-

statistik/fintech/Pages/Statistik-Fintech-Lending-Periode-November-2019.aspx , diakses pada tanggal 19 Januari 2020.

Statistik Fintech, 2018

https://www.ojk.go.id/id/kanal/iknb/data-dan-statistik/Fintech/Default.aspx , diakses pada tanggal 5 Januari 2020.

World Bank, 2019.

https://www.worldbank.org/en/topic/Fintech , diakses pada tanggal 15 Januari 2020. 